\title{
Detection of heavy metal by paper-based microfluidics
}

\author{
Yang Lin ${ }^{\mathrm{a}}$, Dmitry Gritsenko ${ }^{\mathrm{a}}$, Shaolong Feng ${ }^{\mathrm{b}}$, Yi Chen Teh ${ }^{\mathrm{b}}, \mathrm{Xiaonan}_{\mathrm{Lu}}^{\mathrm{b} *}, \mathrm{Jie}_{\mathrm{X}}^{\mathrm{a} *}$ \\ ${ }^{a}$ Mechanical and Industrial Engineering, University of Illinois at Chicago, Chicago, Illinois 60607, \\ USA \\ ${ }^{\mathrm{b}}$ Food, Nutrition and Health Program, Faculty of Land and Food Systems, The University of \\ British Columbia, Vancouver, British Columbia V6T 1Z4, Canada \\ *Corresponding authors: Xiaonan Lu (xiaonan.lu@ubc.ca); Jie Xu (iiexu@uic.edu)
}

\begin{abstract}
Heavy metal pollution has shown great threat to the environment and public health worldwide. Current methods for the detection of heavy metals require expensive instrumentation and laborious operation, which can only be accomplished in centralized laboratories. Various microfluidic paperbased analytical devices have been developed recently as simple, cheap and disposable alternatives to conventional ones for on-site detection of heavy metals. In this review, we first summarize current development of paper-based analytical devices and discuss the selection of paper substrates, methods of device fabrication, and relevant theories in these devices. We then compare and categorize recent reports on detection of heavy metals using paper-based microfluidic devices on the basis of various detection mechanisms, such as colorimetric, fluorescent, and electrochemical methods. To finalize, the future development and trend in this field are discussed.
\end{abstract}

Keywords: Paper-based microfluidics; heavy metal; detection; capillary flow 


\section{Introduction}

The rapid growth of global economy and associated technological progress have caused increased environmental concerns recently (Lu et al. 2015). Heavy metals are among the most problematic pollutants as they are non-biodegradable and can accumulate in ecological systems. In a case of food chain systems, they will eventually result in food chemical contamination which can lead to various diseases, threatening public health (Dai et al. 2012). For instance, cadmium (Cd) accumulates in kidney and liver for over 10 years and affects physiological functions of a human body (López Marzo et al. 2013). Therefore, accurate detection and large-scale monitoring of heavy metal pollution in the environment is extremely important. Many techniques have been developed for the detection of heavy metals, including inductively coupled plasma mass spectrometry (ICPMS) (Djedjibegovic et al. 2012), inductively coupled plasma-atomic/optical emission spectrometry (ICP-AES/OES) (Faraji et al. 2010; Moor et al. 2001), energy dispersive X-ray fluorescence (EDXRF) (Obiajunwa et al. 2002), electrochemical methods (Ma et al. 2015), electrothermal atomic adsorption spectrometry (ETAAS) (Gomez et al. 2007), flame atomic absorption spectrometry (FAAS) (Sohrabi et al. 2013) and atomic absorption spectrophotometry (AAS) (Bagheri et al. 2012). Most of these techniques are of high sensitivity, specificity, and precision; however, all of them require complex equipment, professional personnel, and laborious operations (Cui et al. 2015). Thus, the detection methods that are simple, cost-effective, and portable are highly demanded especially in developing countries and areas with a lack of sufficient infrastructure, professional experts, and appropriate environmental treatment.

In the past two decades, microfluidics has emerged as a promising technology for low-cost and portable sensing applications. The majority of microfluidic devices are based on polydimethylsiloxane (PDMS), a transparent elastomer (Xia and Whitesides 1998). However, these devices are not cheap and portable enough to be widely applied, especially in resourcelimited settings. Recently, paper has been explored as a promising candidate to replace PDMS for "lab-on-a-chip" sensing and detection applications. New terms such as "paper-based microfluidics" and "paper-based analytical devices ( $\mu$ PADs)" have been successfully introduced and attracted growing attention recently (Li et al. 2012b; Martinez et al. 2007; Yetisen et al. 2013). The major principle of paper-based microfluidics is to pattern paper substrates into two different regions: the hydrophilic channels and the hydrophobic barriers. $\mu$ PADs have several advantages over mainstream PDMS-based microfluidic devices. First, it capitalizes on capillary forces instead of extra components (e.g., pumps and tubes) for flow control. Second, its cost is extremely low. In the past few years, $\mu$ PADs applications have grown exponentially with many new promising technologies developed for the detection of various environmental pollutants. In this article, we summarize diverse applications of $\mu$ PADs in the detection of heavy metal ions and provide insights for possible future research directions.

\subsection{Significance of heavy metal detection}

59 Heavy metals are often defined in literature as the metals with densities exceeding $5 \mathrm{~g} / \mathrm{cm}^{3}$ (Yetisen et al. 2013). However, this definition is arguable as it neglects all chemical properties of the substances. In this article, heavy metals are regarded as those metal elements which pollute the environment and jeopardize our food safety, such as plumbum $(\mathrm{Pb})$, cadmium $(\mathrm{Cd})$, mercury $(\mathrm{Hg})$, chromium $(\mathrm{Cr})$, copper $(\mathrm{Cu})$, nickel $(\mathrm{Ni})$, and zinc $(\mathrm{Zn})$.

Cadmium is commonly used in industrial manufacturing and can be applied in electroplating (ElHalim 1984), nuclear fission (McWhirter 2013), as well as routine laboratory uses, such as heliumcadmium lasers (Harries et al. 1995). However, it can post threat to environment and humans 
(Nriagu 1981). For instance, the so-called "itai-itai" disease in Japan was caused by cadmium (Bui et al. 1975). Nickel is another heavy metal that is of high importance for industrial applications. It is widely used in the production of alloys (Carroll et al. 2013), batteries (Yang et al. 2015), and plating (Shao et al. 2014). But nickel has been classified as carcinogen by various agencies and institutions worldwide (Kim et al. 2014b). Additionally, mercury has also been used in diverse applications in the past, including thermometers (Blumenthal 1992), barometers (Peggs et al. 1979), switches (Karnowsky and Yost 1987), and fluorescent lamps (Abreu et al. 2015). This element can cause severe problems to our ecosystem. Therefore, the usage of mercury has been significantly restricted in the past decade. Overall, to mitigate and prevent heavy metal pollution, detection and monitoring of heavy metals is an essential step.

\subsection{Current detection methods}

One of the most reliable and versatile methods of detection of heavy metals is ICP-MS. It has been developed since the 1980s (Bertin et al. 2016; Houk 1986). For instance, Tokalıoğlu (Tokalıoglu 2012) successfully determined different heavy metal elements (e.g., Fe, Sr, Mn, Zn, and Pb) in thirty medicinal herb samples after microwave digestion. Moreover, an ICP-AES-based technique have been developed to detect heavy metal pollutants in wastewater (Isai and Shrivastava 2015). Another common detection method is AAS, which is based on optical absorption. Nowadays, marine pollution has become a worldwide problem and seafood safety has played a crucial role in human health (Höfer 1998). Fatema (Fatema et al. 2015) applied AAS to quantify the concentrations of $\mathrm{Pb}, \mathrm{Cd}, \mathrm{As}, \mathrm{Cr}$, and $\mathrm{Hg}$ in shrimps. Other methods, including EDXRF, ETAAS, and FAAS, are also applied (Chandrasekaran and Ravisankar 2015; Francisco et al. 2015; Mousavi and Derakhshankhah 2014).

Overall, current techniques have advantages in the detection of heavy metals as they are adequately sensitive, specific and accurate for the determination at trace levels (Neves et al. 2009; Saad et al. 2015). However, all of them require expensive and bulky equipment, trained personnel, and laborious operation. Therefore, researchers have been striving to develop cheap, simple, sensitive, specific, accurate, user-friendly, and environmental-friendly detection devices, and $\mu$ PAD is one of the most promising solutions.

\section{Description of microfluidic paper-based analytical devices}

Modern $\mu$ PADs patterned with hydrophobic barriers and hydrophilic areas can be traced back to 1902, and it was designed to prevent cross contamination between different reaction regions (Dieterich 1902). In 1937, Yagoda and colleagues successfully created water-repellent barrier with paraffin wax in filter paper for spot tests (Yagoda 1937). Subsequently, paraffin wax and filter paper were used for $\mathrm{pH}$ determination, water testing, and urine testing (Johnson 1967; Müller and Clegg 1949). Recently, along with the development of "lab-on-a-chip" that aims to shrink and integrate entire analytical procedures onto a single device, $\mu$ PAD has extended its capabilities remarkably, including developments of immunoassays, detection of food chemical hazards and bioterrorism, urinalysis, and environmental monitoring (Maxwell et al. 2013; Zang et al. 2012; Zhang et al. 2015). Moreover, applications of $\mu$ PADs such as mixing (Rezk et al. 2012), separation (Songjaroen et al. 2012), timers (Li et al. 2013), displays (Li and Macdonald 2016), switches(Li et al. 2008), and valves (Jahanshahi-Anbuhi et al. 2014) have also been developed in the past decade. Based on these advancements, $\mu$ PADs have shown great potential for next-generation "lab on a chip" devices. For instance, blood plasma separation has been successfully realized by capillary action on paper substrates with an H-shape channel (Kar et al. 2015). Albeit the separation 
efficiency (75.4\%) is lower than conventional microfluidic chips (99.24\%) (Moon et al. 2011), and it is difficult to collect the as-separated plasma from papers, $\mu$ PADs still exhibited great capabilities in substitution of current chips as they require neither expensive instrumentations, nor professional personnel.

\subsection{Properties and fabrication methods}

Chromatography papers, filter papers, and nitrocellulose membranes are the most commonly used substrates for $\mu$ PADs (Lu et al. 2009b; Nie et al. 2010). Moreover, researchers have also adopted other types of substrates such as glass fiber membranes and fleeces to fabricate $\mu$ PADs. (Fang et al. 2014; Haeberle and Zengerle 2007). Although these substrates possess various favorable properties, a single piece of substrate cannot satisfy all requirements for $\mu$ PADs (Table 1). For example, capillary flow is one of the most crucial properties of $\mu$ PADs by which extra pumps are not required. As the capillary flow rate depends on the size of the pores in the substrates, selection of substrate with desired size of pores should be considered in order to meet the requirements of different applications. Additionally, biocompatibility is decisive for those applications involving biological substances (e.g., proteins). Given this requirement, nitrocellulose membranes are preferred because of their reliable protein binding.

The first modern $\mu$ PADs fabrication method, which depends on polymerization of photoresist, was proposed by the Whitesides's group in 2007 (Martinez et al. 2007). However, this method requires expensive photoresist and complex photolithography process. Later, the same group came up with more rapid and cost-efficient methods of fast lithographic activation of sheets and wax printing in 2008 and 2009 respectively (Carrilho et al. 2009; Martinez et al. 2008). Wax printing hitherto remains the most commonly used method due to its simplicity. It only involves two steps: printing wax patterns onto surface of paper and melting the wax to penetrate the entire thickness of the paper. However, the resolution of this method is only sufficient to simple designs other than complicated ones due to the fact that the spreading of melted wax in porous paper cannot be precisely controlled. Recently, researchers have further developed dozens of fabrication methods (e.g., screen printing, inkjet printing, embossing) for $\mu$ PADs (Table 2). Each of them has its own advantages and disadvantages. Hence, specific applications demand comprehensive consideration of various requirements (e.g., cost, resolution) while choosing fabrication methods. Owing to merits in ease of operation and low cost, printing methods such as wax printing and inkjet printing are considered as the most promising techniques for $\mu$ PADs. However, inherent weaknesses still exist. For instance, functional inks for inkjet printing possess limited windows in viscosity and surface tension (Yamada et al. 2015). Related surfactants in inks can result in denaturation of proteins, and dispersion stabilities of functional nanoparticles in inks can also be diminished while printing. Recent developed methods such as embossing and lamination demonstrate rapid fabrication of $\mu \mathrm{PADs}$ by physical treatments (e.g., cut, lamination) other than using chemicals or inks (Cassano and Fan 2013; Thuo et al. 2014). 
Table 1. Requirements for the substrates of $\mu$ PADs

\begin{tabular}{|c|c|c|}
\hline Requirements & Impacts & Type \\
\hline Absorbency & $\begin{array}{l}\text { Storing sufficient amounts of samples in the devices (Bracher } \\
\text { et al. 2009) }\end{array}$ & Physical \\
\hline Flexibility & $\begin{array}{l}\text { Increasing the resistance of bending and folding especially in } \\
\text { three dimensional structures (Li et al. 2008) }\end{array}$ & Physical \\
\hline Stiffness & Increasing the robustness of the devices & Physical \\
\hline Thermally stable & Enhancing the resistance towards temperature & Physical \\
\hline $\begin{array}{l}\text { High surface-to- } \\
\text { volume ratio }\end{array}$ & $\begin{array}{l}\text { Enhancing the amounts of reactive molecules that immobilized } \\
\text { on the surface of the substrates (Martinez 2011) }\end{array}$ & Physical \\
\hline Capillary flow & $\begin{array}{l}\text { Wicking liquid without the requirement of pumps (Dungchai et } \\
\text { al. 2010) }\end{array}$ & Physical \\
\hline Proper porosity & $\begin{array}{l}\text { Influencing the size of the particles retained in the papers } \\
\text { (Harvey et al. 1996) }\end{array}$ & Physical \\
\hline Proper thickness & $\begin{array}{l}\text { Influencing the visibility, tensile strength, and bed volume of } \\
\text { the substrates }\end{array}$ & Physical \\
\hline Biocompatibility & $\begin{array}{l}\text { Suitability of immunoassay, detection of food contamination } \\
\text { and monitoring of environment (Wang et al. 2012) }\end{array}$ & Chemical \\
\hline Biodegradability & Minimizing the burden to environment & Chemical \\
\hline Low price & $\begin{array}{l}\text { Satisfying the demands of analytical devices in the countries } \\
\text { with low purchasing power (Lu et al. 2009a) }\end{array}$ & Other \\
\hline Lightweight & Achieving in-field applications without bulky equipment & Other \\
\hline High throughput & $\begin{array}{l}\text { Satisfying the demands of developing countries and lower the } \\
\text { price by batch production }\end{array}$ & Other \\
\hline Disposability & Reducing the expenses for post-treatment & Other \\
\hline
\end{tabular}


Table 2. Fabrication methods for $\mu$ PADs

\begin{tabular}{|c|c|c|c|}
\hline Methods & Advantages & Disadvantages & References \\
\hline Laser cutting & $\begin{array}{l}\text { Simple operation; no } \\
\text { chemical contamination }\end{array}$ & $\begin{array}{l}\text { Needs expensive laser cutter; } \\
\text { low resolution }\end{array}$ & $\begin{array}{l}\text { (Bracher et } \\
\text { al. 2009) }\end{array}$ \\
\hline Manual cutting & $\begin{array}{l}\text { Simple operation; no } \\
\text { chemical contamination; } \\
\text { extraordinary cheap }\end{array}$ & Very low resolution & $\begin{array}{l}\text { (Wang et al. } \\
\text { 2010) }\end{array}$ \\
\hline Wax printing & $\begin{array}{l}\text { Simple operation; cheap; } \\
\text { no mask needed }\end{array}$ & $\begin{array}{l}\text { Needs special wax printer; } \\
\text { low resolution; unstable at } \\
\text { high temperatures }\end{array}$ & $\begin{array}{l}\text { (Carrilho et } \\
\text { al. 2009) }\end{array}$ \\
\hline Screen printing & $\begin{array}{l}\text { Suitable for thick layers; } \\
\text { no heating step }\end{array}$ & $\begin{array}{l}\text { Patterned mask is needed; low } \\
\text { resolution }\end{array}$ & $\begin{array}{l}\text { (Dungchai } \\
\text { et al. 2011) }\end{array}$ \\
\hline $\begin{array}{l}\text { Flexographic } \\
\text { printing }\end{array}$ & Low ink consumption & $\begin{array}{l}\text { Requires smooth paper } \\
\text { surface; Requires frequent } \\
\text { cleaning of equipment }\end{array}$ & $\begin{array}{l}\text { (Olkkonen } \\
\text { et al. 2010) }\end{array}$ \\
\hline Inkjet printing & $\begin{array}{l}\text { High efficiency; no mask } \\
\text { is needed; available with } \\
\text { modified office printer }\end{array}$ & $\begin{array}{l}\text { Requires expensive } \\
\text { modification of the office } \\
\text { printer }\end{array}$ & $\begin{array}{l}\text { (Hossain } \\
\text { and Brennan } \\
\text { 2011) }\end{array}$ \\
\hline Laser printing & Simple operation & Needs special ink & $\begin{array}{l}\text { (Bracher et } \\
\text { al. 2009) }\end{array}$ \\
\hline Drawing & Extraordinary cheap & Very low resolution & $\begin{array}{l}\text { (Tai and } \\
\text { Yang 2011) }\end{array}$ \\
\hline Wax dipping & Simple operation; cheap & $\begin{array}{l}\text { Needs a mask and heating } \\
\text { step }\end{array}$ & $\begin{array}{l}\text { (Songjaroen } \\
\text { et al. 2011) }\end{array}$ \\
\hline Plotting & $\begin{array}{l}\text { Suitable for any type of } \\
\text { surface }\end{array}$ & Special plotter is needed & $\begin{array}{l}\text { (Nie et al. } \\
\text { 2012) }\end{array}$ \\
\hline Photolithography & High resolution & $\begin{array}{l}\text { Low resistance to bending and } \\
\text { folding; Expensive fees for a } \\
\text { cleanroom and chemicals }\end{array}$ & $\begin{array}{l}\text { (Martinez et } \\
\text { al. 2007) }\end{array}$ \\
\hline Plasma treatment & $\begin{array}{l}\text { Retains the flexibility of } \\
\text { paper; components like }\end{array}$ & $\begin{array}{l}\text { Requires a mask; heating step } \\
\text { is needed }\end{array}$ & $\begin{array}{l}\text { (Li et al. } \\
\text { 2008) }\end{array}$ \\
\hline
\end{tabular}


switches and filters can be

built directly

\begin{tabular}{|c|c|c|c|}
\hline $\begin{array}{l}\text { Alkenyl ketene } \\
\text { dimer printing }\end{array}$ & $\begin{array}{l}\text { Extremely cheap for } \\
\text { Alkenyl ketene dimer }\end{array}$ & Heating step is needed & $\begin{array}{l}\text { (Li et al. } \\
2010)\end{array}$ \\
\hline Embossing & $\begin{array}{l}\text { Suitable for 3D structure; } \\
\text { simple operation }\end{array}$ & Requires special mold; & $\begin{array}{l}\text { (Thuo et al. } \\
\text { 2014) }\end{array}$ \\
\hline Stereolithography & $\begin{array}{l}\text { Simple operation; suitable } \\
\text { for applications in specific } \\
\text { environment (e.g., high } \\
\text { temperature) }\end{array}$ & $\begin{array}{l}\text { Requires expensive 3D } \\
\text { printer; special mask is } \\
\text { needed }\end{array}$ & $\begin{array}{l}\text { (He et al. } \\
2015)\end{array}$ \\
\hline Lamination & $\begin{array}{l}\text { Cheap; favorable } \\
\text { mechanical strength; } \\
\text { simple operation }\end{array}$ & $\begin{array}{l}\text { Requires digital crafter cutter } \\
\text { and roll laminator }\end{array}$ & $\begin{array}{l}\text { (Cassano } \\
\text { and Fan } \\
\text { 2013) }\end{array}$ \\
\hline Contact Stamping & $\begin{array}{l}\text { Fast and cheap; } \\
\text { reproducible }\end{array}$ & $\begin{array}{l}\text { Requires special ink; low } \\
\text { resolution }\end{array}$ & $\begin{array}{l}\text { (Curto et al. } \\
\text { 2013) }\end{array}$ \\
\hline PDMS printing & Simple operation; cheap & Requires special plotter & $\begin{array}{l}\text { (Bruzewicz } \\
\text { et al. 2008) }\end{array}$ \\
\hline
\end{tabular}

\subsection{Brief theoretical overview}

To describe flow motion in paper which is typically a porous medium, commonly used governing equations include Darcy's law and continuity equation:

$$
V=-\frac{K}{\mu} \nabla P
$$

$$
\nabla \cdot V=0
$$

where $V$ and $P$ are volume-averaged liquid velocity and pore-averaged modified pressure, $K$ is media permeability, and $\mu$ is viscosity of the liquid. Gary and O'Neill (Gray and O'Neill 1976) demonstrated that Darcy's law can be derived from general equations of flow motion by applying local averaging techniques while neglecting convection and inertia. Whitaker (Whitaker 1986) has also provided theoretical derivation of Darcy's law. Although Darcy's law is only suitable for laminar flow, a variety of theoretical models have been developed on its basis throughout the years. Recently, (Masoodi et al. 2007) has considered a case of isotropic porous media which was treated under isothermal conditions. In this study, swelling was not taken into account and the authors proposed five models for the determination of height of liquid front as summarized in Table 3. 
Table 3. Models for the determination of height of liquid front. Adapted with permission from (Masoodi et al. 2007).

Name of Model Equation

Washburn equation

$$
h_{f}=\left(\frac{R_{p} \sigma \cos (\theta)}{4 \tau^{2} \mu} t\right)^{\frac{1}{2}}
$$

Capillary model

$$
h_{f}=\left(\frac{4 K \sigma \cos (\theta)}{\epsilon \mu R_{p}} t\right)^{\frac{1}{2}}
$$

Capillary model with gravity

$$
p_{c} \ln \left|\frac{p_{c}}{p_{c}-\rho g h_{f}}\right|-\rho g h_{f}=\frac{\rho^{2} g^{2} K}{\epsilon \mu} t, p_{c}=2 \sigma \cos (\theta) / R_{p}
$$

EB model

$$
h_{f}=\left(\frac{6 K(1-\epsilon) \sigma \cos (\theta)}{\epsilon^{2} \mu R_{p}} t\right)^{\frac{1}{2}}
$$

EB model with gravity

$$
p_{s} \ln \left|\frac{p_{s}}{p_{s}-\rho g h_{f}}\right|-\rho g h_{f}=\frac{\rho^{2} g^{2} K}{\epsilon \mu} t, p_{s}=\frac{3(1-\epsilon) \sigma \cos (\theta)}{\epsilon R_{p}}
$$

171

However, swelling occurs often during liquid transport in porous media. To combat this problem, Masoodi and colleagues developed a model for porous swelling media (Masoodi and Pillai 2010). Modified versions of Washburn equation and continuity equation appear as follows:

$$
\begin{gathered}
L_{s w}=\left(\sqrt{\frac{\sigma \mathrm{rcos}(\theta)}{2 \mu}}\right)\left[t-\frac{b}{r_{0}} t^{2}+\frac{b^{2}}{r_{0}^{2}} t^{3}\right]^{\frac{1}{2}} \\
\nabla \cdot \mathrm{V}=-\mathrm{S}-\frac{\partial \epsilon}{\partial \mathrm{t}}
\end{gathered}
$$

where $\mathrm{S}$ is a sink that appears due to absorption of liquid. It is assumed that capillary radius decreases linearly: $r=r_{0}-b t$. The second and third terms in $L_{s w}$ also become relatively important at long time intervals.

Additionally, non-Darcy flow considerations should be taken into account at high flow velocities as described by Forchheimer equation:

$$
\frac{\mu}{K} V+\beta \rho V^{2}=-\nabla P
$$

Zeng and Grigg demonstrated that modified Forchheimer number is a better criterion for nonDarcy flows in porous media (Zeng and Grigg 2006). However, non-Darcy flow studies are beyond the scope of this review. Readers can refer to extensive literature for more relevant information (Hassanizadeh and Gray 1987; Huang and Ayoub 2008; Swartzendruber 1962). 
To date, a wide variety of detection methods have been adopted including but not limited to colorimetric, fluorescent, electrochemical, (electro)chemiluminescent, nanoparticles-based, hybrid and others. Despite of such a diversity, the detection of heavy metals with $\mu$ PADs is still in its infancy. The first successive application of $\mu$ PADs is dated back to 2011 (Hossain and Brennan 2011). Since that time these devices have established a reputation for cost-effectiveness, rapidness, high sensitivity, specificity and accuracy and thus considered as promising candidates to detect heavy metals in environmental and agri-food samples.

\subsection{Colorimetric detection}

Colorimetric sensing is one of the most commonly used approaches for laboratory tests and industrial applications, such as the detection of heavy metals in wastewater (Awual and Hasan 2015). This method provides semi-quantitative readouts with the aid of a calibration chart. An example of the commercial products is shown in Figure 1a. In these devices, detection zones are created on paper for simultaneous detection of different analytes. After the sample is loaded and distributed over different reaction zones, chemical reactions of reagents and target analytes occur that allow visual determination of target analytes through the color changes in the reaction zones.

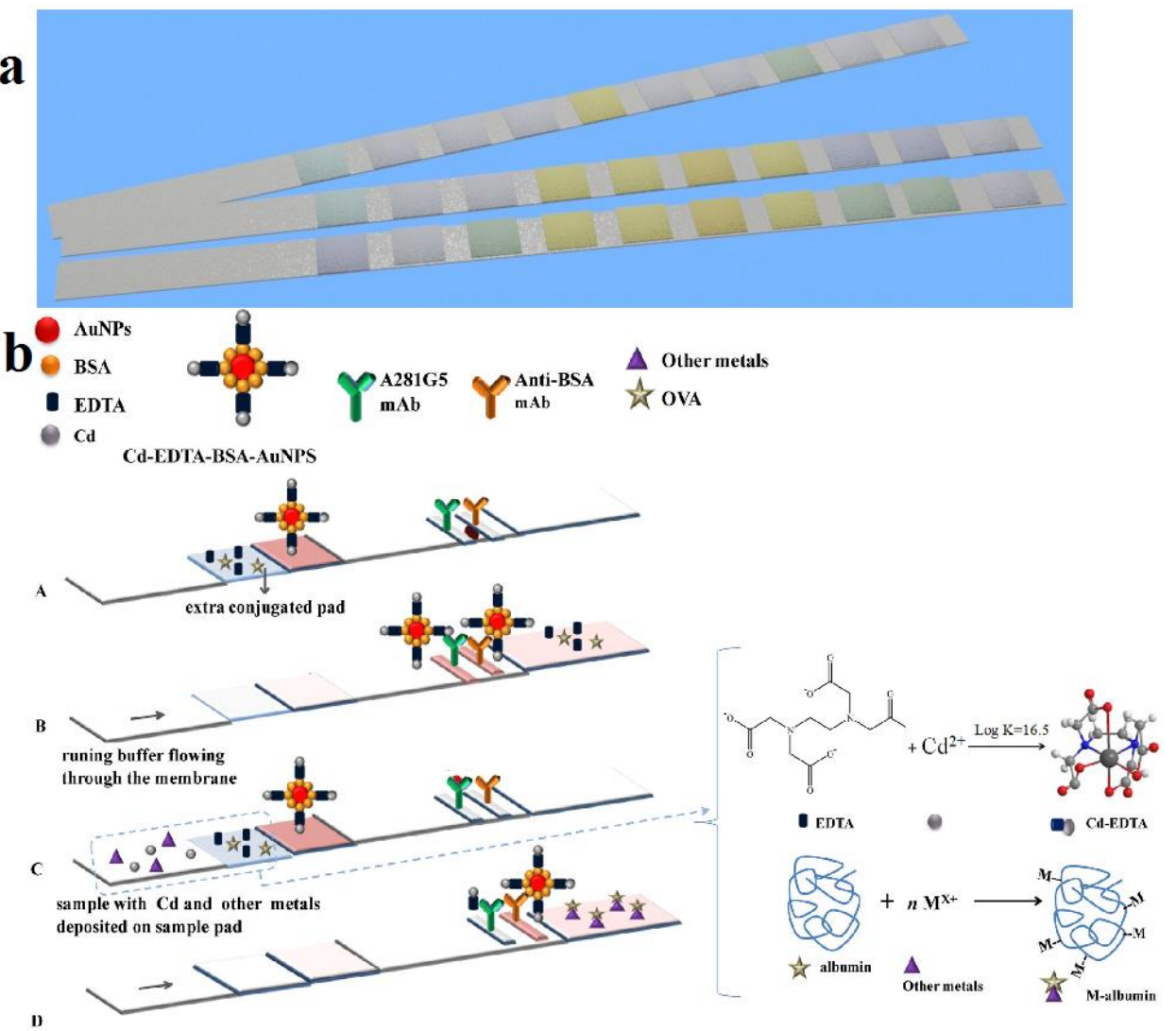

Figure 1. a) Commercially available paper strips with indicated detection zones. b) Schematic illustration of detection of $\mathrm{Cd}^{2+}$ ions based on lateral flow chromatographic immunoassay. Adapted with permission from (López Marzo et al. 2013) 
is shown in Figure 1b (López Marzo et al. 2013). In this study, $\mathrm{Cd}^{2+}$ ions were detected by gold nanoparticles (AuNPs) on the basis of color change. In addition, Lee and Huang developed a $\mu$ PAD for the detection of $\mathrm{Pb}^{2+}$ with the aid of gold nanoparticles (Lee and Huang 2011). Further, $\mathrm{Cu}^{2+}$ ions in aqueous solutions were also detected by paper-based sensor through adding cupron, which was used as chromogenic agent, and the result was optimized by microwave irradiation to reduce reaction time ( $\mathrm{Li}$ et al. 2016). Besides, Chaiyo and coworkers have capitalized on silver nanoplates to determine trace level of $\mathrm{Cu}^{2+}$ ions and demonstrated that the developed $\mu$ PADs have high selectivity even in the presence of more than ten interferential heavy metal ions (Chaiyo et al. 2015). More recently, simultaneous detection of $\mathrm{Hg}^{2+}$ and $\mathrm{Cr}^{3+}$ ions in acetonitrile has been studied by Patidar and colleagues (Patidar et al. 2015). The authors synthesized two types of ionophores that derived from rhodamine, showing great capabilities in specific detection for $\mathrm{Hg}^{2+}$ and $\mathrm{Cr}^{3+}$ ions based on sharp color change (i.e., from colorless to pink for $\mathrm{Hg}^{2+}$ ions, and to reddish-pink for $\mathrm{Cr}^{3+}$ ions).

A versatile $\mu \mathrm{PAD}$ for colorimetric detection of different types of ions has been studied by Wang and colleagues (Wang et al. 2016b). In this study, filter paper was modified by intercalating $\mathrm{Fe}(\mathrm{CN})_{6}{ }^{4-}$ and $\mathrm{S}^{2-}$ into the interlayer of $\mathrm{LDH}$ first. Then, samples were delivered and the concentrations of $\mathrm{Cu}^{2+}, \mathrm{Fe}^{3+}, \mathrm{Pb}^{2+}$, and $\mathrm{Cd}^{2+}$ ions, are determined by the corresponding level of color change. The detection of $\mathrm{Fe}^{3+}$ and $\mathrm{Cu}^{2+}$ in this study is shown in Figure 2a.
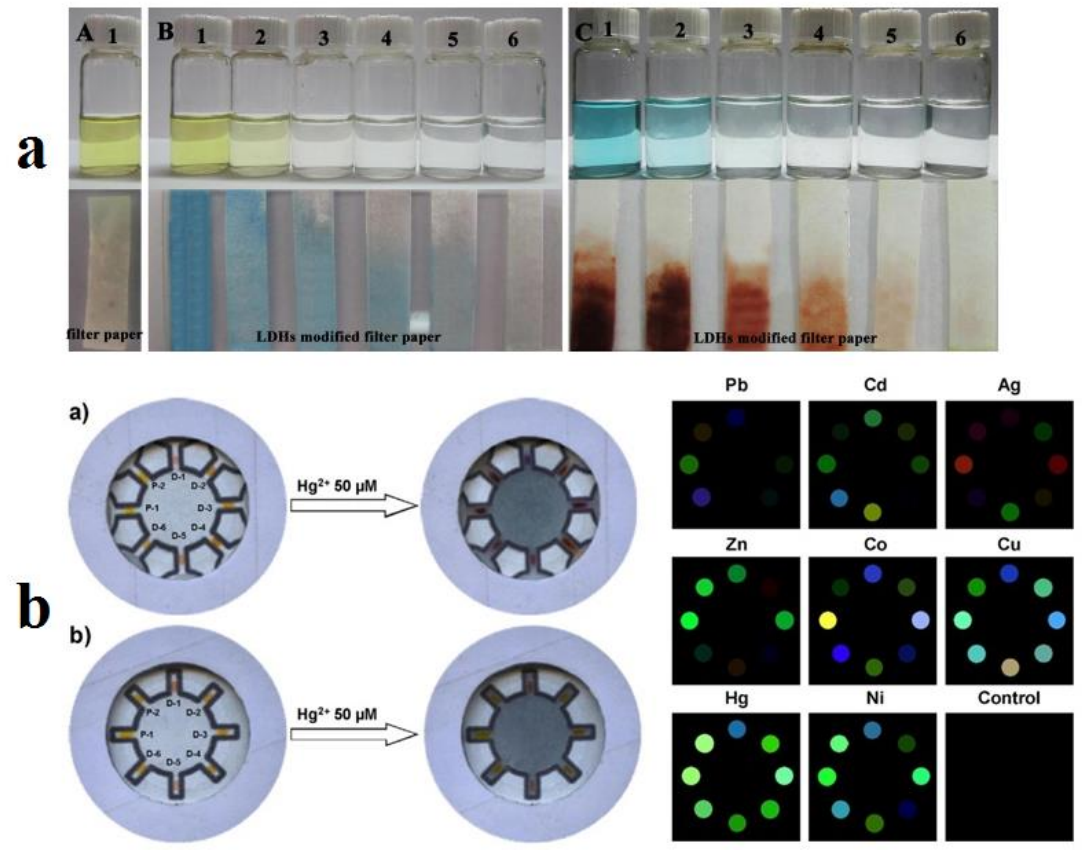

Figure 2. a) A versatile sensor based on $\mu \mathrm{PAD}$. Adapted with permission from (Wang et al. 2016b). b) Distinction of different heavy metal by pattern. Adapted with permission from (Feng et al. 2013b).

Another device employing enrichment-based technique proposed by Feng (Feng et al. 2013b) has been validated to possess higher sensitivity than the regular colorimetric methods. A paper array (Figure 2b) with eight pyridylazo compounds was selected to function as the indicator of eight corresponding ions, including $\mathrm{Ni}^{2+}, \mathrm{Hg}^{2+}$, and $\mathrm{Cu}^{2+}$ ions. Interestingly, another similar design of 
colorimetric array on filter paper also showed great potential for the recognition of different types of ions (Liu and Lin 2014).

As a popular method, colorimetric technique plays an important role in the detection of heavy metals during the past decade. The aforementioned examples are far from exhaustive and more studies can be found in (Hossain and Brennan 2011; Jayawardane et al. 2013; Kaewtong et al. 2014; Kim et al. 2014a; Li et al. 2015; Mentele et al. 2012; Puangploy et al. 2014; Rashid et al. 2016; Rattanarat et al. 2013; Wang et al. 2016a; Xiang et al. 2015). The main drawbacks of colorimetric-based detection method include possible release of toxic gases during operation as well as low sensitivity and selectivity. Nevertheless, colorimetric method is still promising and has great potential for improvement in near future.

\subsection{Fluorescent detection}

Another commonly used detection method is a fluorescent one. Compared to colorimetric, it exhibits higher sensitivity and selectivity (Zheng et al. 2013). To recognize target analytes (e.g., heavy metal ions), chelating agent (i.e., receptor) should be applied for efficient interaction with analytes. Besides, chelating units are connected with fluorophore units to generate recognizing fluorescence whether enhancing or quenching its intensity (Formica et al. 2012).

Recent extensions of current method aimed to develop more efficient fluorescent substances and faster detection technique for trace level of heavy metal ions (Aragay et al. 2012; de Almeida et al. 2012; Kim et al. 2015; Peng et al. 2014). For instance, Zheng and collaborators proposed to use a luminescent metal-organic framework as a fluorescent probe to detect $\mathrm{Fe}^{3+}$ ions on filter paper (Zheng et al. 2013). The limit of detection (LOD) was as low as $0.0005 \mathrm{~mol} / \mathrm{L}$ and the fluorescent reaction to $\mathrm{Fe}^{3+}$ ions could be finished in one minute. Song and coworkers have developed a chemosensor to detect $\mathrm{Cu}^{2+}$ ions in aqueous solution on the basis of aggregation-induced emission (Song et al. 2014). Alternative approach for the same ions was developed by Liu and colleagues (Liu et al. 2012) with the aid of silver nanoclusters (AgNCs) whose fluorescent properties can be quenched in the presence of $\mathrm{Cu}^{2+}$ ions. After immobilization of AgNCs on a surface of filter paper, an excellent linear relationship between fluorescent response and the concentrations of $\mathrm{Cu}^{2+}$ ions has been demonstrated (Figure 3a). 

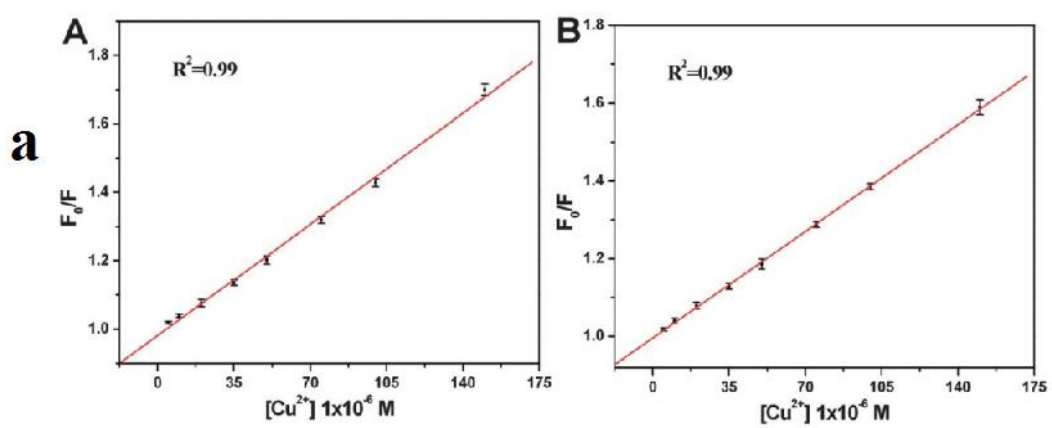

b
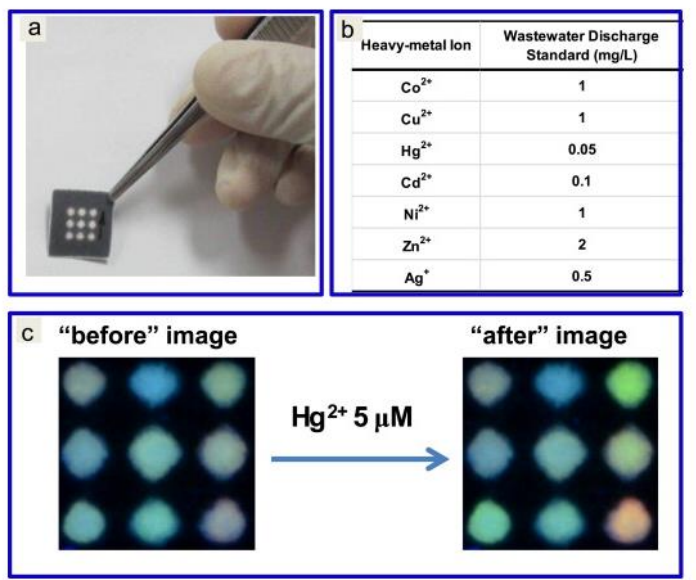

Figure 3. a) Relationship between fluorescent response and the concentrations of $\mathrm{Cu}^{2+}$ ions in the test of A) drinking water, and B) river water. Adapted with permission from (Liu et al. 2012). b) Example of "fingerprint" based on pattern-recognition methods. Adapted with permission from (Feng et al. 2013a).

In a pioneering study reported by Hatai and coworkers, determination of heavy metal ions in animal and human cells has been achieved (Hatai et al. 2012). The authors developed a histidinebased fluorescent chemosensor to detect $\mathrm{Hg}^{2+}$ ions and showed that the histidine modified by attachment of a bipodal thiocarbamate scaffold exhibited favorable selectivity. They further demonstrated the feasibility of chemosensor for paper strips. Eventually, this method was used to image the distribution of $\mathrm{Hg}^{2+}$ ions in zebrafish and human cells.

Recently, Zhang and collaborators achieved the simultaneous determination of heavy metal contaminations in foods on a single paper strip by graphene oxide that was modified by fluorescent agent labeled single-stranded DNA (Zhang et al. 2015). Fluorescent technique has also been applied for multiplex detection (Feng et al. 2013a). A series of novel fluorescent indicators based upon 4, 4-difluoro-4-bora-3a, 4a-diaza-s-indacene were developed for testing real wastewater samples. Based upon pattern-recognition methods, different metal ions were distinguished successfully. For instance, the pattern for $\mathrm{Hg}^{2+}$ with concentration of $5 \mu \mathrm{M}$ is shown in Figure $3 \mathbf{b}$ as a "fingerprint".

\subsection{Electrochemical detection}

Traditional electrochemical technique usually involves a three-electrode system (Newman and Thomas-Alyea 2012), including a working electrode, a counter electrode, and a reference electrode. Technically speaking, with only two electrodes, an electrochemical measurement can still be carried out (Lei et al. 2011; Li et al. 2012a; Rivera et al. 2015; Zhao et al. 2012). However, 
as the concentration of analytes is reduced due to chemical reaction, the potential drop on the working electrode occurs, which will deteriorate the sensing performance. Therefore, a reference electrode with a stable potential can be incorporated to adjust the potential of the working electrode. At present, various electroanalytical methods, including cyclic voltammetry, square wave voltammetry, linear sweep voltammetry, staircase voltammetry, anodic stripping voltammetry, cathodic stripping voltammetry, adsorptive stripping voltammetry, and chronoamperometry have been studied and applied (Scholz 2010). In the past decade, the applications of electrochemical sensing with $\mu$ PADs has been extended significantly (Nie et al. 2010; Ruecha et al. 2016; Shi et al. 2012). In these applications, the working and counter electrodes are usually fabricated by printing carbon ink on the paper while the reference electrode is commonly made of silver/silver chloride $(\mathrm{Ag} / \mathrm{AgCl})$. To date, screen printing is the most popular method used for printing these conductive electrodes on a paper substrate. Other simple methods such as drawing are also possible (Dossi et al. 2013). Additionally, gold can be used as an alternative material for electrodes because of its excellent conductivity (Carvalhal et al. 2010).

301 Compared with colorimetric and fluorescent methods used in $\mu$ PADs, electrochemical method has 302 even more rapid response and higher sensitivity (less than $1 \mu \mathrm{M}$ ) (Yetisen et al. 2013), and is more 303 preferred for achieving better quantitative results. For instance, the detection of $\mathrm{Pb}^{2+}$ and $\mathrm{Cd}^{2+}$ ions in aqueous medium has been successfully achieved on filter paper strips based on electrochemical technique by Shi and colleagues (Shi et al. 2012). Additionally, determination of heavy metal ions (e.g., $\mathrm{Hg}^{2+}, \mathrm{Ag}^{+}, \mathrm{Cr}^{3+}$ ions) in real groundwater has been demonstrated by Lee and collaborates (Lee et al. 2014) recently. In this study, polypyrrole/cellulose composite paper was applied. Polypyrrole provides favorable electrochemical properties while the cellulose paper offers sufficient mechanical strength. They demonstrated that this composite paper based device serves as a multiplex detector for various heavy metals by unique signatures under analysis of principal component analysis. Another application was proposed by Ruecha (Ruecha et al. 2015). The electrodes were modified by nanocomposite of graphene-polyaniline and conventional screen printing method was employed to fabricate three-electrode system on filter paper. Potentiostat was utilized to detect trace level of ions such as $\mathrm{Zn}^{2+}, \mathrm{Cd}^{2+}$, and $\mathrm{Pb}^{2+}$ by square-wave anodic stripping voltammetry. The schematic illustration of fabrication process for this $\mu$ PAD is given in Figure 4. 


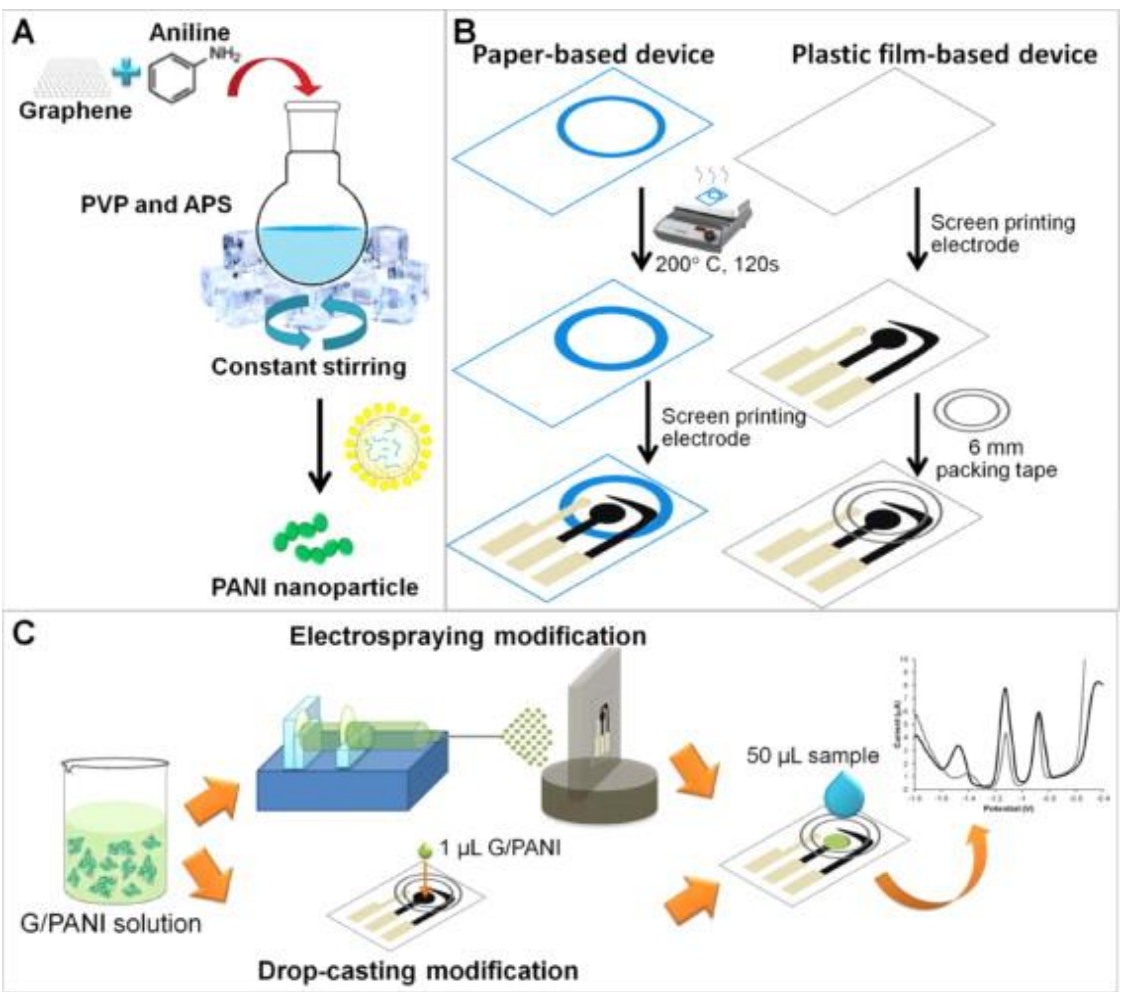

317 Figure 4. Schematic illustration of fabrication process. Adapted with permission from (Ruecha et 318 al. 2015).

\section{3.4 Chemiluminescent detection and Electrochemiluminescent detection} generated by chemical reaction of two reactants under catalyst or excited intermediate instead of fluorescence (Cormier 2013; Wang et al. 2009). Two different mechanisms exist in the process of chemiluminescence: one is that the emitting species are generated directly by the oxidation of reagents while the other one is through enhancing or inhibiting the effects of luminescent compounds (Chen et al. 2014). However, the chemiluminescence from inorganic molecules is very weak, and various enhancing methods have been developed (Guo et al. 2013; Yang et al. 2012). Similarly, electrochemiluminescent technique depends on the luminescence produced by electrochemical reactions. Technically speaking, the emitted light is generated based on the electron transfer reactions, which happen between the electrogenerated radical cations and anions (Swanick et al. 2012). Through the electron transfer reactions, excited states of intermediates are formed and light is emitted consequently.

Even though these two techniques have been explored for various applications of $\mu$ PADs, the applications in heavy metal detection are still limited (Liu et al. 2014; Zhang et al. 2013). Recently, Liu (Liu et al. 2014) demonstrated the feasibility of applying chemiluminescence to detect $\mathrm{Hg}^{2+}$ ions through $\mu$ PADs. In this study, aptamers, which are artificial single-stranded DNA or RNA, were utilized to recognize and capture $\mathrm{Hg}^{2+}$ ions. Zhang (Zhang et al. 2013) applied two types of electrochemiluminescent nanoprobe based on oligonucleotide to detect $\mathrm{Pb}^{2+}$ and $\mathrm{Hg}^{2+}$ ions, respectively. Besides, silica nanoparticles, which were modified by carbon nanoclusters, and $R u(b p y)_{3}^{2+}$ conjugated gold nanoparticles served as electrochemiluminescent labels for corresponding detection. The schematic illustration of this study is shown in Figure 5. 


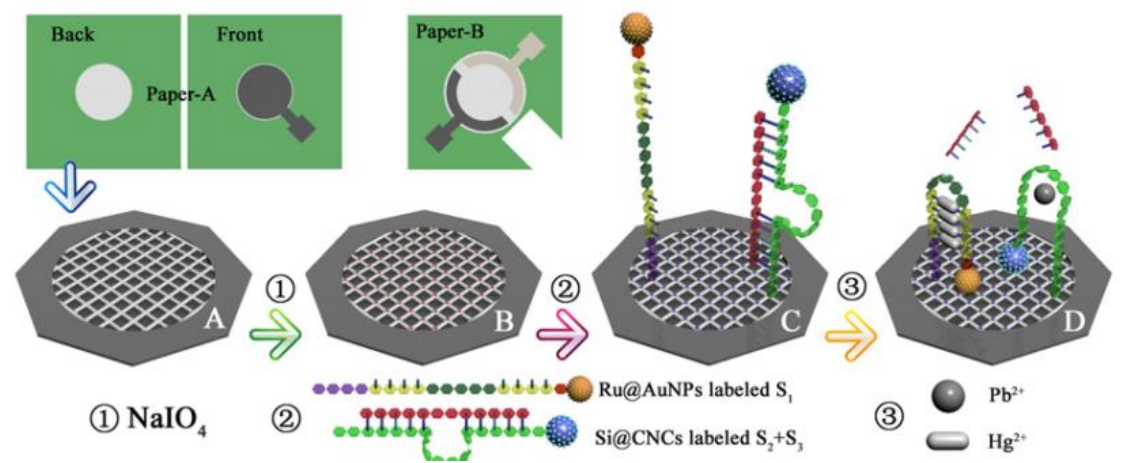

Figure 5. Schematic illustration for the detection of $\mathrm{Pb}^{2+}$ and $\mathrm{Hg}^{2+}$ ions based on electrochemiluminescent technique. Adapted with permission from (Zhang et al. 2013).

\subsection{Nanoparticles based detection}

Detection based on nanoparticles (e.g., gold nanoparticles, silver nanoparticles) usually involves other techniques such as colorimetric method (Chaiyo et al. 2015; Fang et al. 2015; Nath et al. 2014; Patidar et al. 2015). Due to good performance as a recognizable indicator for naked eye, nanoparticles usually do not require readers for qualitative detections. Additionally, nanoparticles have good affinity to target analytes (e.g., heavy metal ions) for forming conjugates. Nanoparticles have been successfully employed for heavy metal ions detection with $\mu$ PADs recently (Elavarasi et al. 2013; Fang et al. 2015; Vijitvarasan et al. 2015). For instance, Nath and cowokers have successfully detected trace level of $\mathrm{As}^{3+}$ ions with nanoparticles in a $\mu$ PAD (Nath et al. 2014). In this study, Au-TA-TG was prepared by conjugating gold nanoparticles, thioctic acid (TA), and thioguanine (TG) under the presence of EDC/NHS. As shown in Figure 6, gold nanosensor $\mathrm{Au}-$ TA-TG and sample with $\mathrm{As}^{3+}$ ions were introduced to different inlets of the device, and conjugated with each other, leading to the color change on the surface of the paper that indicated the presence of $\mathrm{As}^{3+}$ ions in the sample. 
of the device, different types of heavy metal ions were detected simultaneously. As shown in Figure 7a, $\mathrm{Fe}^{3+}, \mathrm{Ni}^{2+}, \mathrm{Cr}^{3+}$ and $\mathrm{Cu}^{2+}$ ions were determined by colorimetric method in the top layer while $\mathrm{Cd}^{2+}$ and $\mathrm{Pb}^{2+}$ ions were determined by three-electrode electrochemical method in the bottom layer of the device.

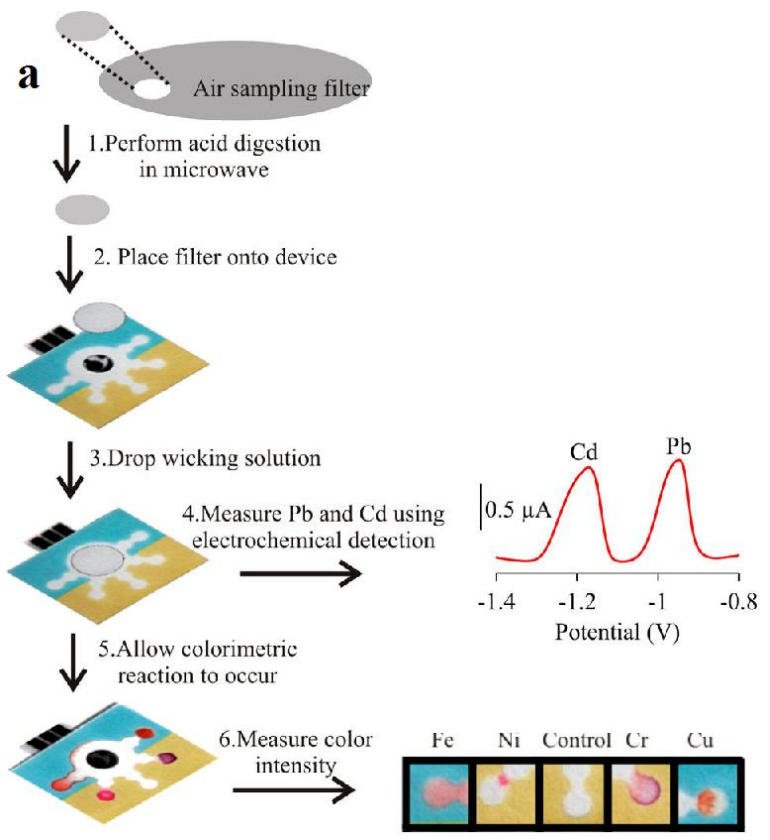

b

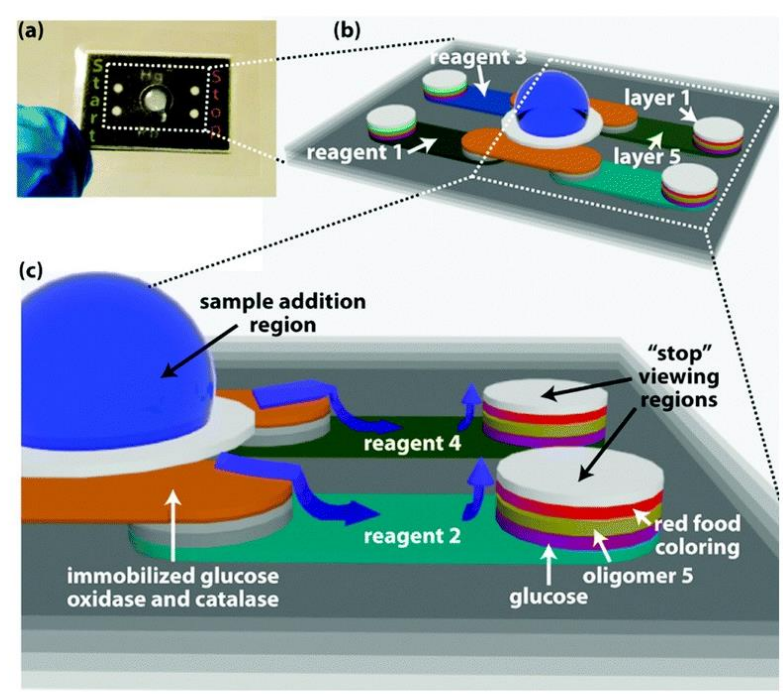

371

372

373

374

375

376

377

378

379

380

381

382

383

384

385

386

387

388

389

390

391

392

393

Figure 7. a) Simultaneous detection for different heavy metal ions based on colorimetric and electrochemical techniques in a single device. Adapted with permission from (Rattanarat et al. 2014). b) Determination of $\mathrm{Hg}^{2+}$ and $\mathrm{Pb}^{2+}$ ions in water through measurement of time. Adapted with permission from (Lewis et al. 2014).

Conventional methods such as colorimetric, fluorescent, and electrochemical techniques usually ask for an extra reader to quantify the concentration of target analytes in the sample, thus increasing the costs of using $\mu$ PADs. Recently, several novel methods have emerged for detection or readout. For instance, Lewis developed a simple method to quantify the level of $\mathrm{Hg}^{2+}$ and $\mathrm{Pb}^{2+}$ ions in water by measuring time between reactions on the regions of "START" or "STOP" which occurred at different time as shown in Figure 7b (Lewis et al. 2014). Additionally, surface-enhanced Raman scattering (SERS) has also been adopted to detect $\mathrm{Hg}^{2+}$ with ultra-sensitivity (She et al. 2016). Recently, $\mathrm{Pb}^{2+}$ and $\mathrm{Cd}^{2+}$ ions have been determined by an integrative field analytical system (Lin et al. 2016). In this study, cellulose filter paper was modified by immobilization of $\mathrm{TiO}_{2}$, and it showed great adsorption capacity for these two ions. Afterwards, quantification of ions was achieved by a portable X-ray fluorescence spectrometer.

\section{Conclusions and future perspectives}

Although the applications of paper-based microfluidics for the detection of heavy metals are still in its early stage and no real product has emerged, huge progress has been developed in various aspects, such as sensitivity, selectivity, response time, and cost-effectiveness. Numerous properties of a paper substrate can influence the performance of $\mu$ PADs and thus require careful selection. Dozens of fabrication methods became currently available, such as wax printing, inkjet printing, and photolithography. However, cheap fabrication methods with a comparable high resolution are 
394 still in demand. At present, colorimetric method is still the main one applied in paper-based devices 395 for the detection of heavy metal ions. Nevertheless, low LOD and challenges in quantitative 396 detection encourage researches for further innovations. Other detection techniques, such as 397 electrochemical, chemiluminescent, and hybrid techniques might be preferred. However, these 398 methods often call for expensive chemicals or extra equipment, which are not desirable for mass 399 adoption. Thus, quantitative methods with simple fabrication and operation are still in demand.

400 Overall, a bright future for the comprehensive detection of heavy metals in a single paper-based 401 device can be expected. We envisage that the real products for the detection of heavy metal 402 pollution based upon $\mu$ PADs are around the corner.

403 Acknowledgements

404 We acknowledge financial support from Sigma Xi Grants-in-Aid of research. 


\section{References}

Abreu, A.S., Mayer, J., Knoll, M., Konrad, A., Tidecks, R., Horn, S., 2015. LEUKOS 11(2), 89-92.

Aragay, G., Montón, H., Pons, J., Font-Bardía, M., Merkoçi, A., 2012. Journal of Materials Chemistry 22(13), 5978-5983.

Awual, M.R., Hasan, M.M., 2015. Sensors and Actuators B: Chemical 206, 692-700.

Bagheri, H., Afkhami, A., Saber-Tehrani, M., Khoshsafar, H., 2012. Talanta 97, 87-95.

Bertin, R.L., Maltez, H.F., de Gois, J.S., Borges, D.L., Borges, G.d.S.C., Gonzaga, L.V., Fett, R., 2016. Journal of Food Composition and Analysis.

Blumenthal, I., 1992. Journal of the Royal Society of Medicine 85(9), 553.

Bracher, P.J., Gupta, M., Mack, E.T., Whitesides, G.M., 2009. ACS applied materials \& interfaces 1(8), 18071812.

Bruzewicz, D.A., Reches, M., Whitesides, G.M., 2008. Analytical chemistry 80(9), 3387-3392.

Bui, T.-H., Lindsten, J., Nordberg, G.F., 1975. Environmental research 9(2), 187-195.

Carrilho, E., Martinez, A.W., Whitesides, G.M., 2009. Analytical chemistry 81(16), 7091-7095.

Carroll, L., Cabet, C., Carroll, M., Wright, R., 2013. International Journal of Fatigue 47, 115-125.

Carvalhal, R.F., Simão Kfouri, M., de Oliveira Piazetta, M.H., Gobbi, A.L., Kubota, L.T., 2010. Analytical chemistry 82(3), 1162-1165.

Cassano, C.L., Fan, Z.H., 2013. Microfluidics and nanofluidics 15(2), 173-181.

Chaiyo, S., Siangproh, W., Apilux, A., Chailapakul, O., 2015. Analytica chimica acta 866, 75-83.

Chandrasekaran, A., Ravisankar, R., 2015. Spectrochimica Acta Part A: Molecular and Biomolecular Spectroscopy.

Chen, H., Lin, L., Li, H., Lin, J.-M., 2014. Coordination Chemistry Reviews 263, 86-100.

Cormier, M., 2013. Chemiluminescence and bioluminescence. Springer Science \& Business Media.

Cui, L., Wu, J., Ju, H., 2015. Biosensors and Bioelectronics 63, 276-286.

Curto, V.F., Lopez-Ruiz, N., Capitan-Vallvey, L.F., Palma, A.J., Benito-Lopez, F., Diamond, D., 2013. RSC Adv. 3(41), 18811-18816.

Dai, B., Cao, M., Fang, G., Liu, B., Dong, X., Pan, M., Wang, S., 2012. Journal of hazardous materials 219, 103-110.

de Almeida, E., do Nascimento Filho, V.F., Menegario, A.A., 2012. Spectrochimica Acta Part B: Atomic Spectroscopy 71, 70-74.

Dieterich, K., 1902. Testing-paper and method of making same. Google Patents.

Djedjibegovic, J., Larssen, T., Skrbo, A., Marjanović, A., Sober, M., 2012. Food Chemistry 131(2), 469-476. Dossi, N., Toniolo, R., Pizzariello, A., Impellizzieri, F., Piccin, E., Bontempelli, G., 2013. Electrophoresis 34(14), 2085-2091.

Dungchai, W., Chailapakul, O., Henry, C.S., 2010. Analytica chimica acta 674(2), 227-233.

Dungchai, W., Chailapakul, O., Henry, C.S., 2011. Analyst 136(1), 77-82.

El-Halim, A.A., 1984. Journal of applied electrochemistry 14(5), 587-594.

Elavarasi, M., Rajeshwari, A., Chandrasekaran, N., Mukherjee, A., 2013. Analytical Methods 5(21), 62116218.

Fang, X., Wei, S., Kong, J., 2014. Lab on a Chip 14(5), 911-915.

Fang, X., Zhao, Q., Cao, H., Liu, J., Guan, M., Kong, J., 2015. Analyst 140(22), 7823-7826.

Faraji, M., Yamini, Y., Saleh, A., Rezaee, M., Ghambarian, M., Hassani, R., 2010. Analytica chimica acta 659(1), 172-177.

Fatema, K., Naher, K., Choudhury, T., Islam, M., Tamim, U., Hossain, S., Islam, S., 2015. Journal of Environmental Analytical Chemistry 2015.

Feng, L., Li, H., Niu, L.-Y., Guan, Y.-S., Duan, C.-F., Guan, Y.-F., Tung, C.-H., Yang, Q.-Z., 2013a. Talanta 108, 103-108.

Feng, L., Li, X., Li, H., Yang, W., Chen, L., Guan, Y., 2013b. Analytica chimica acta 780, 74-80. 
Formica, M., Fusi, V., Giorgi, L., Micheloni, M., 2012. Coordination Chemistry Reviews 256(1), 170-192. Francisco, B.B.A., Brum, D.M., Cassella, R.J., 2015. Food chemistry 185, 488-494.

Gomez, M.R., Cerutti, S., Sombra, L.L., Silva, M.F., Martínez, L.D., 2007. Food and Chemical Toxicology 45(6), 1060-1064.

Gray, W.G., O'Neill, K., 1976. Water Resources Research 12(2), 148-154.

Guo, C., Zeng, H., Ding, X., He, D., Li, J., Yang, R., Qu, L., 2013. Journal of Luminescence 134, 888-892.

Haeberle, S., Zengerle, R., 2007. Lab on a Chip 7(9), 1094-1110.

Harries, M.L., Lam, S., MacAulay, C., Qu, J., Palcic, B., 1995. The Journal of Laryngology \& Otology 109(02), 108-110.

Harvey, M.A., Audette, C.A., McDonogh, R., 1996. IVD Technol 2, 34.

Hassanizadeh, S.M., Gray, W.G., 1987. Transport in porous media 2(6), 521-531.

Hatai, J., Pal, S., Jose, G.P., Bandyopadhyay, S., 2012. Inorganic chemistry 51(19), 10129-10135.

He, Y., Wu, W.-b., Fu, J.-z., 2015. RSC Advances 5(4), 2694-2701.

Höfer, T., 1998. Water Research 32(12), 3505-3512.

Hossain, S.Z., Brennan, J.D., 2011. Analytical chemistry 83(22), 8772-8778.

Houk, R., 1986. Analytical chemistry 58(1), 97A-105A.

Huang, H., Ayoub, J.A., 2008. SPE Journal 13(01), 112-122.

Isai, K., Shrivastava, V., 2015. Journal of Advanced Chemical Sciences, 164-166.

Jahanshahi-Anbuhi, S., Henry, A., Leung, V., Sicard, C., Pennings, K., Pelton, R., Brennan, J.D., Filipe, C.D., 2014. Lab on a Chip 14(1), 229-236.

Jayawardane, B.M., Cattrall, R.W., Kolev, S.D., 2013. Analytica chimica acta 803, 106-112. Johnson, J.L., 1967. Microchimica Acta 55(4), 756-762.

Kaewtong, C., Uppa, Y., Srisa-ard, M., Pulpoka, B., Tuntulani, T., 2014. RSC Advances 4(86), 46145-46151. Kar, S., Maiti, T.K., Chakraborty, S., 2015. Analyst 140(19), 6473-6476.

Karnowsky, M.M., Yost, F.G., 1987. Mercury switch with non-wettable electrodes. Google Patents. Kim, H., Na, Y.J., Song, E.J., Kim, K.B., Bae, J.M., Kim, C., 2014a. RSC Advances 4(43), 22463-22469. Kim, K.-H., Shon, Z.-H., Mauulida, P.T., Song, S.-K., 2014b. Chemosphere 111, 312-319. Kim, Y., Jang, G., Lee, T.S., 2015. ACS applied materials \& interfaces 7(28), 15649-15657. Lee, J.E., Shim, H.W., Kwon, O.S., Huh, Y.-I., Yoon, H., 2014. Analyst 139(18), 4466-4475. Lee, Y.-F., Huang, C.-C., 2011. ACS applied materials \& interfaces 3(7), 2747-2754. Lei, N., Li, P., Xue, W., Xu, J., 2011. Measurement science and technology 22(10), 107002. Lewis, G.G., Robbins, J.S., Phillips, S.T., 2014. Chemical Communications 50(40), 5352-5354. Li, J.-j., Ji, C.-h., Hou, C.-j., Huo, D.-q., Zhang, S.-y., Luo, X.-g., Yang, M., Fa, H.-b., Deng, B., 2016. Sensors and Actuators B: Chemical 223, 853-860.

Li, J., Macdonald, J., 2016. Lab on a Chip 16(2), 242-245.

Li, M., Cao, R., Nilghaz, A., Guan, L., Zhang, X., Shen, W., 2015. Analytical chemistry 87(5), 2555-2559.

Li, P., Lei, N., Xu, J., Xue, W., 2012a. Nanotechnology, IEEE Transactions on 11(4), 751-759.

Li, X., Ballerini, D.R., Shen, W., 2012b. Biomicrofluidics 6(1), 011301.

Li, X., Tian, J., Garnier, G., Shen, W., 2010. Colloids and surfaces B: Biointerfaces 76(2), 564-570.

Li, X., Tian, J., Nguyen, T., Shen, W., 2008. Analytical chemistry 80(23), 9131-9134.

Li, X., Zwanenburg, P., Liu, X., 2013. Lab on a chip 13(13), 2609-2614.

Lin, X., Li, S.-X., Zheng, F.-Y., 2016. RSC Advances 6(11), 9002-9006.

Liu, F., Wang, S., Zhang, M., Wang, Y., Ge, S., Yu, J., Yan, M., 2014. Microchimica Acta 181(5-6), 663-670.

Liu, L., Lin, H., 2014. Analytical chemistry 86(17), 8829-8834.

Liu, X., Zong, C., Lu, L., 2012. Analyst 137(10), 2406-2414.

López Marzo, A.M., Pons, J., Blake, D.A., Merkoçi, A., 2013. Analytical chemistry 85(7), 3532-3538.

Lu, Y., Shi, W., Jiang, L., Qin, J., Lin, B., 2009a. Electrophoresis 30(9), 1497-1500.

Lu, Y., Shi, W., Qin, J., Lin, B., 2009b. Analytical chemistry 82(1), 329-335. 
Lu, Y., Song, S., Wang, R., Liu, Z., Meng, J., Sweetman, A.J., Jenkins, A., Ferrier, R.C., Li, H., Luo, W., 2015. Environment international 77, 5-15.

Ma, H., An, R., Chen, L., Fu, Y., Ma, C., Dong, X., Zhang, X., 2015. Electrochemistry Communications 57, 1821.

Martinez, A.W., 2011. Bioanalysis 3(23), 2589-2592.

Martinez, A.W., Phillips, S.T., Butte, M.J., Whitesides, G.M., 2007. Angewandte Chemie International Edition 46(8), 1318-1320.

Martinez, A.W., Phillips, S.T., Wiley, B.J., Gupta, M., Whitesides, G.M., 2008. Lab on a Chip 8(12), 21462150.

Masoodi, R., Pillai, K.M., 2010. AlChE journal 56(9), 2257-2267.

Masoodi, R., Pillai, K.M., Varanasi, P.P., 2007. AlChE journal 53(11), 2769-2782.

Maxwell, E.J., Mazzeo, A.D., Whitesides, G.M., 2013. MRS bulletin 38(04), 309-314.

McWhirter, J.D., 2013. Heat Exchanger, Methods Therefor and a Nuclear Fission Reactor System. Google Patents.

Mentele, M.M., Cunningham, J., Koehler, K., Volckens, J., Henry, C.S., 2012. Analytical chemistry 84(10), 4474-4480.

Moon, H.-S., Kwon, K., Kim, S.-I., Han, H., Sohn, J., Lee, S., Jung, H.-I., 2011. Lab on a Chip 11(6), 1118-1125. Moor, C., Lymberopoulou, T., Dietrich, V.J., 2001. Microchimica Acta 136(3-4), 123-128.

Mousavi, H.Z., Derakhshankhah, J., 2014. Journal of AOAC International 97(6), 1707-1712.

Müller, R., Clegg, D.L., 1949. Analytical chemistry 21(9), 1123-1125.

Nath, P., Arun, R.K., Chanda, N., 2014. RSC Advances 4(103), 59558-59561.

Neves, R.C., Moraes, P.M., Saleh, M.A., Loureiro, V.R., Silva, F.A., Barros, M.M., Padilha, C.C., Jorge, S.M., Padilha, P.M., 2009. Food Chemistry 113(2), 679-683.

Newman, J., Thomas-Alyea, K.E., 2012. Electrochemical systems. John Wiley \& Sons.

Nie, J., Zhang, Y., Lin, L., Zhou, C., Li, S., Zhang, L., Li, J., 2012. Analytical chemistry 84(15), 6331-6335.

Nie, Z., Deiss, F., Liu, X., Akbulut, O., Whitesides, G.M., 2010. Lab on a Chip 10(22), 3163-3169.

Nriagu, J.O., 1981.

Obiajunwa, E., Pelemo, D., Owolabi, S., Fasasi, M., Johnson-Fatokun, F., 2002. Nuclear Instruments and Methods in Physics Research Section B: Beam Interactions with Materials and Atoms 194(1), 61-64.

Olkkonen, J., Lehtinen, K., Erho, T., 2010. Analytical chemistry 82(24), 10246-10250.

Patidar, R., Rebary, B., Paul, P., 2015. Journal of fluorescence 25(2), 387-395.

Peggs, G., Elliott, K., Lewis, S., 1979. Metrologia 15(2), 77.

Peng, L., Zhou, Z., Wang, X., Wei, R., Li, K., Xiang, Y., Tong, A., 2014. Analytica chimica acta 829, 54-59.

Puangploy, P., Smanmoo, S., Surareungchai, W., 2014. Sensors and Actuators B: Chemical 193, 679-686.

Rashid, M.I., Mujawar, L.H., Ismail, I., El-Shahawi, M.S., 2016. Analytical Methods.

Ratnarathorn, N., Chailapakul, O., Henry, C.S., Dungchai, W., 2012. Talanta 99, 552-557.

Rattanarat, P., Dungchai, W., Cate, D., Volckens, J., Chailapakul, O., Henry, C.S., 2014. Analytical chemistry 86(7), 3555-3562.

Rattanarat, P., Dungchai, W., Cate, D.M., Siangproh, W., Volckens, J., Chailapakul, O., Henry, C.S., 2013. Analytica chimica acta 800, 50-55.

Rezk, A.R., Qi, A., Friend, J.R., Li, W.H., Yeo, L.Y., 2012. Lab on a Chip 12(4), 773-779.

Rivera, C.M., Kwon, H.-J., Hashmi, A., Yu, G., Zhao, J., Gao, J., Xu, J., Xue, W., Dimitrov, A.G., 2015. Sensors 15(5), 10465-10480.

Ruecha, N., Rodthongkum, N., Cate, D., Chailapakul, O., Henry, C., 2016. une 13, 15.

Ruecha, N., Rodthongkum, N., Cate, D.M., Volckens, J., Chailapakul, O., Henry, C.S., 2015. Analytica chimica acta 874, 40-48.

Saad, G., Bedeer, A., Radwan, E., 2015. Journal of Oceanography and Marine Science 6(1), 1-19. Scholz, F., 2010. Electroanalytical methods. Springer. 
Shao, Z., Cai, Z., Hu, R., Wei, S., 2014. Surface and Coatings Technology 249, 42-47. She, P., Chu, Y., Liu, C., Guo, X., Zhao, K., Li, J., Du, H., Zhang, X., Wang, H., Deng, A., 2016. Analytica chimica acta 906, 139-147.

Shi, J., Tang, F., Xing, H., Zheng, H., Lianhua, B., Wei, W., 2012. Journal of the Brazilian Chemical Society 23(6), 1124-1130.

Sohrabi, M.R., Matbouie, Z., Asgharinezhad, A.A., Dehghani, A., 2013. Microchimica Acta 180(7-8), 589597.

Song, P., Xiang, Y., Wei, R.R., Tong, A., 2014. Journal of Luminescence 153, 215-220.

Songjaroen, T., Dungchai, W., Chailapakul, O., Henry, C.S., Laiwattanapaisal, W., 2012. Lab on a Chip 12(18), 3392-3398.

Songjaroen, T., Dungchai, W., Chailapakul, O., Laiwattanapaisal, W., 2011. Talanta 85(5), 2587-2593.

Swanick, K.N., Ladouceur, S., Zysman-Colman, E., Ding, Z., 2012. Chemical Communications 48(26), 31793181.

Swartzendruber, D., 1962. Journal of Geophysical Research 67(13), 5205-5213.

Tai, Y.-L., Yang, Z.-G., 2011. Journal of Materials Chemistry 21(16), 5938-5943.

Thuo, M.M., Martinez, R.V., Lan, W.-J., Liu, X., Barber, J., Atkinson, M.B., Bandarage, D., Bloch, J.-F., Whitesides, G.M., 2014. Chemistry of Materials 26(14), 4230-4237.

Tokalıoğlu, Ş., 2012. Food chemistry 134(4), 2504-2508.

Vijitvarasan, P., Oaew, S., Surareungchai, W., 2015. Analytica chimica acta 896, 152-159.

Wang, C.-Y., Fang, B.-Y., Yao, M.-H., Zhao, Y.-D., 2016a. Sensors and Actuators B: Chemical.

Wang, N., Sun, J., Fan, H., Ai, S., 2016b. Talanta 148, 301-307.

Wang, S., Ge, L., Song, X., Yu, J., Ge, S., Huang, J., Zeng, F., 2012. Biosensors and bioelectronics 31(1), 212218.

Wang, W., Wu, W.-Y., Zhu, J.-J., 2010. Journal of Chromatography A 1217(24), 3896-3899.

Wang, Z., Chin, S.Y., Chin, C.D., Sarik, J., Harper, M., Justman, J., Sia, S.K., 2009. Analytical chemistry 82(1), 36-40.

Whitaker, S., 1986. Transport in porous media 1(1), 3-25.

Xia, Y., Whitesides, G.M., 1998. Annual review of materials science 28(1), 153-184.

Xiang, X., Zhang, Z., Shi, J., Huang, F., 2015. RSC Advances 5(4), 2615-2619.

Yagoda, H., 1937. Industrial \& Engineering Chemistry Analytical Edition 9(2), 79-82.

Yamada, K., Henares, T.G., Suzuki, K., Citterio, D., 2015. Angewandte Chemie International Edition 54(18), 5294-5310.

Yang, C., Manohar, A.K., Prakash, G.S., Narayanan, S., 2015. Properties of Nickel-Iron Batteries with HighPerformance Iron Electrodes. Meeting Abstracts, pp. 702-702. The Electrochemical Society. Yang, L., Guan, G., Wang, S., Zhang, Z., 2012. The Journal of Physical Chemistry C 116(5), 3356-3362. Yetisen, A.K., Akram, M.S., Lowe, C.R., 2013. Lab on a Chip 13(12), 2210.

Zang, D., Ge, L., Yan, M., Song, X., Yu, J., 2012. Chemical Communications 48(39), 4683-4685.

Zeng, Z., Grigg, R., 2006. Transport in Porous Media 63(1), 57-69.

Zhang, M., Ge, L., Ge, S., Yan, M., Yu, J., Huang, J., Liu, S., 2013. Biosensors and Bioelectronics 41, 544-550. Zhang, Y., Zuo, P., Ye, B.-C., 2015. Biosensors and Bioelectronics 68, 14-19. Zhao, J., Hashmi, A., Xu, J., Xue, W., 2012. Applied Physics Letters 100(24), 243109. Zheng, M., Tan, H., Xie, Z., Zhang, L., Jing, X., Sun, Z., 2013. ACS applied materials \& interfaces 5(3), 10781083. 